Jofrid Karner Smidt

Førsteamanuensis ved Høgskolen i Oslo

\title{
Litteratursosiologi og estetikk - Jan Mukařovský revisited
}

\section{Sammendrag}

Den litteratursosiologiske forskningen har vært sped og sporadisk i Norge. Det gjelder særlig empiriske undersøkelser av litteraturlesing, resepsjon og litteraturopplevelse. En medvirkende årsak kan være at teoriene på feltet er lite utviklet. Artikkelen argumenterer for at Jan Mukařovskýs estetiske teori fortjener fornyet interesse i denne sammenhengen. Formidlingen av Mukařovskýs arbeider innenfor delvis fransk-strukturalistiske, delvis post-strukturalistiske rammer, kan ha medvirket til at hans bidrag til resepsjonsestetikken har kommet i bakgrunnen. Det er derfor grunn til å behandle denne siden av hans estetikk mer systematisk.Målet med denne artikkelen er å styrke det teoretiske grunnlaget for empiriske resepsjonsstudier gjennom en analyse av Jan Mukařovskýs estetikk betraktet i et litteratursosiologisk perspektiv. Artikkelen drøfter særlig begrepene funksjon, intensjonalitet og verdi, og viser hvordan disse kan vœre fruktbare analysekategorier for resepsjonstekster, ikke minst kvalitative leserintervjuer.

\section{Innledning}

I innføringsboka Moderne litteraturteori skriver Hans H. Skei om resepsjonsteorien: “Til tross for en klar vridning i moderne litteraturteori mot leseren, er teoriene om lesere og lesning ennå lite utviklet...” (Skei 1993: 53). Formuleringen skriver seg fra originalutgaven fra 1993, og har fått stå uendret siden. Mangelen på teoretisk belysning kan være med på å forklare at den empiriske forskningen på feltet har vært sped og sporadisk her hjemme. Men da må det også nevnes at forskere som arbeider med lesersosiologiske problemstillinger nærmest overser en av de mest interessante tilgangene, tsjekkeren Jan Mukařovskýs arbeider. Jan Mukařovský kom allerede i trettiårene fram til noen av de samme innsiktene om sammenhenger mellom sosiale forskjeller og kulturbruk som Pierre Bourdieu siden har fått så sterkt gjennomslag for, men han har en langt dypere interesse for og innsikt i selve resepsjonsprosessens kompleksitet. I den store Encyclopedia of Contemporary Literary Theory, også den fra 1993, står det å lese: "However, among all of Mukařovskýs texts, [...] Aesthetic Function, Norm and Value as Social Facts 1936 plays a special role as it revolutionizes European aesthetic theory in fewer than 75 pages" (Le Grand: 430). Hva som er det betydningsfulle ved Mukařovskýs estetiske teori sett i et litteratursosiologisk perspektiv skal være denne artikkelens tema, men la meg først knytte en kort kommentar til resepsjonen av Mukařovský i Norge ${ }^{1}$.

\footnotetext{
${ }^{1}$ Spørsmålet om resepsjonen av Mukařovský i Skandinavia er behandlet utførlig i Karen Gammelgaards artikkel “Den skandinaviske reception af Pragerskolens litteraturvidenskab” (Gammelgaard 2003b).
} 
Mukařovský ble introdusert for et skandinavisk publikum i 1971 med Christian Kocks antologi Tjekkisk strukturalisme (Kock 1971) og Kurt Aspelin og Bengt Lundbergs utvalg i Form och struktur (Aspelin og Lundberg 1971). I Norge var det de litteraturvitenskapelige miljøene i Oslo og Bergen som først bidro til å gjøre Mukařovský kjent. Arild Linneberg spilte en sentral rolle i denne sammenhengen ${ }^{2}$. Mukařovský får senere omtale i flere av kapitlene i Moderne litteraturteori: en innføring (Kittang et.al. 1993) ${ }^{3}$ og er representert med artikkelen “Intensjonalitet og ikke-intensjonalitet i kunsten” i Moderne litteraturteori: en antologi (Kittang et al. 1991). Den siste større behandlingen av Mukařovskýs estetiske teori fra skandinavisk litteraturvitenskapelig hold kom med Lars Sætres grundige artikkel "Intensjonalitet som problem i Jan Mukařovskýs litterære estetikk” i Edda 1989. Sætres prosjekt er både å klargjøre ulike aspekter ved Mukařovskýs intensjonalitetsbegrep, og å lese Mukařovskýs litteraturteori inn i den da høyst aktuelle post-strukturalistiske forståelsesrammen med koblinger til Derrida, Kristeva, Barthes og de Mans tekstteoretiske univers ${ }^{4}$. Siden ser det ut som Mukařovský hovedsakelig har blitt lest ut fra en rent historisk interesse i de litteraturvitenskapelige miljøene.

Det er framfor alt i semiotikkmiljøene, representert blant annet ved forskergruppen Tekst/Historie og sakprosamiljøet i Oslo, at Mukařovský har blitt aktualisert de siste femten årene. Særlig har Karen Gammelgaard, Kjell Lars Berge og Johan Tønnesson vært viktige formidlere ${ }^{5}$. Ser vi imidlertid på forskere som har interessert seg for litteratursosiologiske problemstillinger med forankring i fagmiljøene medier og kommunikasjon eller sosiologi, er det Konstanzerskolen og senere særlig Bourdieu som har vært teoretiske premissleverandører ${ }^{6}$.

Det er flere grunner, slik jeg ser det, til at Mukařovskýs skrifter ikke har fått den oppmerksomhet de fortjener i det litteratursosiologiske miljøet hos oss. 1. Han skriver hovedsakelig på tsjekkisk ${ }^{7}$. 2. De engelske oversettelsene er gamle og vanskelige å få tak i. 3. De norske oversettelsene kom i forbindelse med boomen for strukturalistisk teori på 70-tallet, og er preget av en bestemt lesemåte: Mukařovský som link mellom den russiske formalismen, den langt mer

\footnotetext{
${ }^{2}$ Antologien Strukturalisme i litteraturvitenskapen: en presentasjon av sentrale navn innenfor Prager-skolen, redigert av Anders Heldal og Arild Linneberg (1978) var betydningsfull. Av tidlige studier med et delvis resepsjonsestetisk siktemål må nevnes Arild Linnebergs avhandling Arne Garborgs Haugtussa - en analyse av kunstverket i kommunikasjonen (Linneberg 1979). Mukařovskýs normbegrep ligger blant annet til grunn for Linnebergs analyse av en nyromantisk kontra en realistisk-naturalistisk lesning av Haugtussa.

${ }^{3}$ Se Linneberg, A. s. 15-17 og 166-167, Melberg, A. s. 65 og 67, Kittang, A. s. 95 ff i Moderne litteraturteori: en innføring (Kittang et al. 1993).

${ }^{4}$ Siden Sætre og jeg forholder oss til de samme tekstene, artikkelen om intensjonalitet i særdeleshet, vil det nødvendigvis være flere paralleller mellom hans og min Mukařovský-presentasjon. Siktemålet for de to artiklene er imidlertid høyst forskjellig. Jeg ønsker å vise hvordan Mukařovský kan berike litteratursosiologien, empiriske resepsjonsstudier i særdeleshet, teoretisk og metodisk. Sætre ønsker å vise hvordan Mukařovský foregriper poststrukturalistiske teoridannelser, “(...) den evige utsetjinga av Meining og Forankring” (Sætre 1989: 325), en tolkning jeg mener er presset.

${ }^{5}$ Se særlig Karen Gammelgaards faglig helt sentrale introduksjon til Pragerskolen i Tekstens mening fra 2003, Kjell Lars Berge (1990) Tekstnormers diakroni og behandlingen av Mukařovský i Asdal, K. et al. (2008). Tekst og historie. Tønnesson, J. (2004). Tekst som partitur diskuterer intensjonalitetsbegrepet.

${ }^{6}$ Nettopp av den grunn kommer jeg sporadisk til å trekke paralleller til Bourdieus arbeider utover i artikkelen. ${ }^{7}$ Det er likevel verd å merke seg at Mukařovský skrev noen få artikler og konferanseinnlegg på fransk. Her kan altså den ikke-tsjekkiskkyndige få tilgang til Mukařovskýs egne formuleringer. Dette gjelder for eksempel tre av artiklene gjengitt i Structure, Sign and Function (Mukařovský 1977a), blant annet "Can there be a Universal Aesthetic Value in Art” med originaltittelen “La valeur esthétique dans l’art peut-elle être universelle?” Legg merke til betydningsnyansen!
} 
berømte Roman Jakobsons teorier og den franske strukturalismen. 4. De norske oversettelsene av Mukařovskýs viktigste verk er forkortelser, og utelatelsene er preget av den fransk-strukturalistiske lesemåten ${ }^{8}$. Dette gjelder særlig Arild Linnebergs "Estetisk verdi som sosialt faktum” (Mukařovský 1978) som er en oversettelse av kun siste del av den før nevnte Aesthetic Function, Norm and Value as Social Facts. De to første delene, som er meget viktige for resepsjonsteorien, er bare representert ved sammendrag som ikke er spesielt fyllestgjørende. Men også i Jo Eggens oversettelse av den sentrale “Intensjonalitet og ikke-intensjonalitet i kunsten” (Mukařovský 1943/1991), er innsiktsgivende eksempler utelatt. Utelatelsene er meget diskret markert ved prikker i klammer, mens utelatelser av til dels lange, interessante fotnoter overhodet ikke er markert ${ }^{9}$. Til dette kan det legges at Mukařovskýs arbeider har preg av "work in progress”. Han beveget seg år for år bort fra sitt formalistiske utgangspunkt med verkets struktur som det vesentlige spørsmålet, og mot en stadig større interesse også for et resepsjonsteoretisk perspektiv, inspirert av fenomenologien. Hans akademiske karriere som fri tenker ble imidlertid brått bitt av etter den kommunistiske maktovertakelsen i 1948 (Gammelgaard 2003a: 11-12). I 1951 fikk Mukařovský valget mellom enten å bli avsatt som professor eller å ta avstand fra sine tidligere betraktningsmåter. Til mange av fagfellenes forferdelse valgte han det siste, noe som ikke nettopp bidro til økt promovering av hans teorier fra kollegenes side. Men dette minsker ikke deres betydning og relevans.

Mukařovskýs arbeider fra midten av trettitallet og utover formulerer en estetikk som konsekvent tar utgangspunkt i persepsjonen eller betraktningsmåten. Publikums aktive resepsjon er avgjørende for bestemmelsen av det estetiske området. Her er han på linje med profilerte representanter for 1900-tallets estetiske teori som Gadamer og Dewey (Gadamer 1977 og Dewey 1934/1958). Mukařovský bringer det sosiale perspektivet inn i estetikken, og foregriper, som antydet innledningsvis, på mange måter Bourdieu på kultursosiologiens område ${ }^{10}$. Samtidig har de senere arbeidene hans klare forbindelseslinjer til Bakhtinskolen når det gjelder å forstå leseprosessens dialogiske karakter.

Mukařovský favner vidt. Han analyserer i arbeidene sine et bredt spekter av kulturuttrykk, fra arkitektur, over film og billedkunst til litteratur. En viktig vinning ved hans perspektiv er at han ikke splitter opp det estetiske området i kunst, brukskunst og andre estetiserte ting eller aktiviteter, men ser det som et hele, der skillet mellom kunst og andre estetiske fenomen er flytende. Det får som konsekvens at også sakprosa fruktbart kan betraktes i lys av hans teori om kulturytringer.

Målet med denne artikkelen er å presentere Mukařovskýs bidrag til litteratursosiologien og vise dens relevans for empiriske leserundersøkelser knyttet til skjønnlitteratur så vel som sakprosa. Men jeg vil også avslutningsvis argumentere for at Mukařovskýs teoriutvikling mot slutten av forfatterskapet ikke representerer en raffinering av en strukturalisme med formalistiske røtter, men i realiteten et paradigmeskifte. Det er nettopp denne nyorienteringen som fører hans tenkning nær opp mot Bakhtinskolens dialogisme.

\footnotetext{
${ }^{8}$ Siden jeg ikke behersker tsjekkisk, er jeg stort sett (med unntak av de nevnte franskspråklige tekstene) henvist til å sammenlikne med engelske og tyske oversettelser, og må for øvrig støtte meg på vurderinger fra forskere som Karen Gammelgaard, som leser Mukařovský på originalspråket.

${ }^{9}$ Det informeres ikke om forkortelsene i ingressen som redaktørene av antologien står ansvarlige for.

${ }^{10}$ Parallellene har vært påpekt før, blant annet i Linneberg 1993: 167, og er på visse områder så mange at man i blant kan få fornemmelsen av at Mukařovský er Bourdieus unevnte forelegg.
} 


\section{Spørsmålet om funksjon}

La meg først behandle Mukařovskýs funksjonsbegrep slik det utvikles særlig i Aesthetic Function, Norm and Value as Social Facts 1936 og i "The Place of the Aesthetic Function among the Other Functions” fra 1942. Det skiller seg avgjørende fra Roman Jakobsons strukturalistiske funksjonsbegrep. Mens Roman Jakobson er opptatt av å bestemme grunnleggende funksjoner i språket og disse funksjonenes manifestering i tekster (Jakobson 1960/1978), er Mukařovskýs fenomenologisk inspirerte funksjonsbegrep knyttet til betraktningsmåter og menneskets bruk av gjenstander og kulturytringer, noe som igjen er forbundet med kulturelle fellesskap og sosiale vaner. Det er (den sosialt situerte) betrakteren, brukeren eller leseren, som bestemmer tingens eller ytringens funksjon.

Et annet viktig aspekt ved Mukařovskýs funksjonsbegrep, er at all menneskelig aktivitet er grunnleggende polyfunksjonell ${ }^{11}$. Ingen områder av menneskelig aktivitet er i seg selv forbeholdt bare én funksjon. Litteratur vil alltid ha en kommunikativ funksjon ved siden av eventuelle estetiske funksjoner. Sakprosa vil ofte tillegges en større eller mindre grad av estetisk funksjon ved siden av eksempelvis kunnskapsformidlende funksjoner. Arkitektur kan betraktes gjennom alt fra sin rene nyttefunksjon til kunst, alt etter betrakterens interesse. Samtidig presiserer Mukařovský at den differensieringen mellom den estetiske funksjon og andre funksjoner som vi ser i moderniteten, ikke gjør seg gjeldende i førmoderne samfunn. Her kan vi som Mukařovský hente eksempler fra folkekunsten. På 1700-tallet var mangletreet en yndet festegave i mange norske bygder. Et fint utskåret mangletre hadde flere funksjoner: den rent praktiske - et redskap til å rulle og glatte tøy med, den estetiske - å være øyenslyst i kraft av sin utsmykning, den symbolske - å bekrefte en forlovelse, og kanskje også representere festmannens dugelighet. Det kunne til og med bli sett på som et symbol på festekvinnens dyrebarhet: jo finere utarbeidet festegave, jo mer dyrebar den utkårede. Alle disse funksjonene var tett sammenvevet.

Det faktum at enhver menneskelig handling ledsages av et helt knippe av funksjoner, skaper et behov for å bestemme forholdet mellom dem. Mukařovský opererer i forskjellige kontekster med et mangfold av funksjonsbetegnelser (for eksempel kommunikativ, estetisk, magisk, pedagogisk, kognitiv), men utarbeider tentativt en typologi med fire hovedtyper: de praktiske og symbolske funksjoner på den ene siden og den teoretiske (eller bedre: kognitive) og den estetiske funksjon på den andre siden (Mukařovský 1942/1977a: 31-48) ${ }^{12}$. Disse bestemmes i første rekke i forhold til menneskets måter å forholde seg til omverdenen på, og hvorvidt det er den ytre verden eller det sansende subjekt selv som bearbeides eller påvirkes. Når noe tillegges praktisk funksjon, er det det instrumentelle, ønsket om å bearbeide verden med tingen som redskap som er det sentrale. Når noe tillegges symbolsk eller rituell funksjon, er oppmerksomheten også rettet utover, mot noe som skal skapes, representeres eller forandres, slik en nasjonalsang kan representere et fellesskap, eller en gjennomhullet dukke kan representere en fiende man vil skade. Litteratur kan også få en symbolsk funksjon når et bestemt verk eller forfatterskap blir uttrykk for at leseren tilhører en interessegruppe eller innehar et visst mål av det vi med Bourdieu kan kalle kulturell kapital. Når noe derimot tillegges kognitiv funksjon, er det betrakteren eller leseren som påvirkes. Det er leserens egen kunnskap eller innsikt som utvikles. Og når den estetiske

\footnotetext{
${ }^{11}$ Her på linje med Jakobson.

${ }^{12}$ Se også Steiner 1977: xxvii - xxix.
} 
funksjon aktiveres, står også subjektet og subjektets opplevelse i sentrum. Det er leseren eller betrakteren det skjer noe med (Mukařovský 1942/1977a).

Mukařovský konstaterer at den estetiske funksjonen omfatter et mye videre aktivitetsområde enn kunsten, og videre at ingen fenomen i kraft av sine iboende egenskaper nødvendigvis har en estetisk funksjon, uavhengig av tid og sted. Heller ikke er det i prinsippet noen fenomen som ikke kan tillegges en estetisk funksjon. Det kan være nok å henvise til estetiseringen av stadig nye områder, klær, mat, vektleggingen av design i bruksgjenstander. Kulturuttrykk kan brukes på mange måter, og tingenes eller tekstenes funksjon varierer både historisk og sosialt. Et veggmaleri som hadde estetisk funksjon i en epoke, kan miste den og overmales. En tekst som hadde estetisk funksjon i en periode, kan virke parodisk i en annen tid, mens en annen tekst kan tillegges en estetisk funksjon den tidligere ikke hadde. For samtidens publikum kunne det estetiske og saklig beskrivende ved Nordlands Trompet neppe skilles fra hverandre, mens diktet i dag hovedsakelig har estetisk funksjon. Tilsvarende kan en tekst tillegges en nærmest praktisk funksjon i ett sosialt fellesskap, for eksempel et fotografi som dokumenterer en begivenhet, mens den samme teksten kan tillegges en estetisk funksjon i en annen sosial kontekst.

Slik sett blir grensene for estetikkens domene flytende. Endrer man

perspektiv i tid og sosialt rom, endres også den estetiske funksjonens utbredelse og grenser (Mukařovský 1936/1970: 4). I én kontekst kan grensene oppfattes som relativt faste, i en annen som vage. Det følger av dette at også kunstens grenser er foranderlige. Kunsten skiller seg fra andre estetiske fenomen først og fremst ved hvilken rolle den estetiske funksjon tillegges. Mukařovskýs forståelse går ut på at når noe bestemmes som kunst, betyr det at det legges avgjørende vekt på tingen eller tekstens estetiske funksjon. Som Bourdieu hevder Mukařovský at avgrensningen av kunstens felt til enhver tid er knyttet til grupper som har definisjonsmakt på feltet (Mukařovský 1936/1970: 47, se også s. 53, 55, 58). Men Mukařovský tar høyde for at også andre befolkningsgrupper anvender kunstbegrepet, med til dels avvikende kunstforståelser som grunnlag. Skal man forstå litteraturens liv i samfunnet, slik kultursosiologien har som mål, er disse gruppenes forståelse like interessante. Det er ikke nok å konstatere at disse andre publikumsgruppene har en uren smak, betraktet med utgangspunkt i en dominerende posisjon. Det blir kultursosiologiens, eller når det gjelder litteraturen: litteratursosiologiens, oppgave å undersøke utbredelsen av den estetiske funksjon i forhold til andre funksjoner i konkrete historiske og sosiale kontekster.

I intervjuer med lesere blir man slått av hvordan tekster, eller la oss nå si litteratur, kan ha ulike funksjoner i ulike miljø og for ulike lesere. Litteratur kan tillegges en rent instrumentell funksjon, eller den kan få symbolsk funksjon, som når det å ha lest en bestemt tekst gir status, kulturell kapital, eller tilhørighet til en bestemt gruppe. Men litteratur tillegges også i svært mange tilfeller en kognitiv funksjon: man får kunnskap eller ny innsikt ved å lese, skjønnlitteratur så vel som sakprosa. Og ikke minst vil en litterær tekst kunne gi en estetisk opplevelse. Den estetiske funksjon, sier Mukařovský, kjennetegnes ved at den har en tendens til å fjerne eller isolere tingen eller teksten fra praktiske funksjoner, forsterke oppmerksomheten rettet mot teksten selv og ikke minst dens form. Den kjennetegnes ganske særlig av at den er forbundet med lyst eller glede. Dessuten har den en evne til å skape sosial differensiering, og anvendes derfor av høyere 
sosiale lag som en distingverende faktor (Mukařovský 1936/1970: 21-22) ${ }^{13}$. Mukařovský skrev med andre ord allerede i 1936 om “distinksjonen”.

Mukařovskýs mangefasetterte funksjonsbegrep gir et redskap til å beskrive forskjeller mellom lesere, forskjeller mellom dominerende lesemåter i ulike miljø og aldersgrupper og dermed til å bestemme karakteristiske trekk ved ulike gruppers forhold til kulturytringer. Det gir mulighet til å sammenlikne ulike leseres tilnærming og studere kulturelle grenseoppganger. Dybdeintervjuer kan tyde på at den "vanlige” leser, forstått som en som ikke har et profesjonelt forhold til litteraturen, ikke prioriterer den estetiske funksjon (ikke prioriterer form over funksjon, som Bourdieu ville si), og heller ikke er seg bevisst noe tydelig skille mellom litteraturens eksempelvis kognitive og estetiske funksjoner. Her er et eksempel, hentet fra et intervju med en mannlig leser i førtiårene:

\begin{abstract}
Merabs skönhet av Torgny Lindgren er en av mine store leseropplevelser. Det var ett eller annet der, hele stemningen, jeg både lo og grein mange ganger i løpet av den lille boka. Det Torgny Lindgren fikk til der, det har han aldri vœrt i næerheten av siden. Det måtte væere noe i livet hans, har jeg tenkt, som gjorde at han hadde tilgang på en spesiell slags visdom. Og så den måten han skriver på! Nei, jeg klarer ikke å tenke på den boka uten å bli rørt, jeg, sånn som han skildrer de menneskene. Det er ikke bare stemningen, det er språket også. Det er poesi i alt. (Smidt 2010, manuskript) ${ }^{14}$
\end{abstract}

Det er kombinasjonen av "visdom” og “poesi” denne leseren verdsetter. Når lesere beskriver leseropplevelser, blir det i mange tilfeller åpenbart at litteraturens estetiske funksjon er tett sammenvevet med en kunnskapsutvidende funksjon, slik som i følgende utsagn fra en annen mannlig leser som nesten utelukkende leser sakprosa:

Jeg leser ikke skjønnlitteratur. Det har jeg slutta med for mange år sida. Det fascinerer meg ikke. Jeg har prøvd flere ganger, men det blir en 30-40 sider og så orker jeg ikke mer. For meg er lesing både kunnskap og underholdning, begge deler. Det er veldig tilfredsstillende å lese noen som virkelig har greie på ting. Ting du ikke visste sjøl. Men det er jo også underholdning. Hvis det bare var et herk og et slit, sjøl om du fikk med deg et korn her og der, så veit jeg ikke om jeg hadde giddi... (Smidt 2010, manuskript).

Variasjoner når det gjelder litteraturens funksjoner gir én viktig inngang til karakteristikken av forskjeller i litteraturopplevelsen.

\title{
Intensjonalitet og ikke-intensjonalitet
}

I “Intentionality and Unintentionality in Art”, opprinnelig et foredrag holdt i Prags lingvistiske sirkel i 1943, bygger Mukařovský ut sin resepsjonsteori. Her er det selve persepsjonsprosessen, eller mer spesifikt: leseprosessen det er snakk om. Også her bruker Mukařovský ulike kunstneriske uttrykk fra bildekunst, skulptur, teaterforestillinger og lyriske tekster som eksempler. Det

\footnotetext{
13 "Due to its isolating properties, the aesthetic function can also become a socially differentiating factor; cp. the greater sensitivity toward the aesthetic function, and its more intensive utilization, in the higher levels of society which attempt to distinguish themselves from the other social levels..." Synspunktet utdypes videre i teksten.

${ }^{14}$ Intervjuet er hentet fra mitt forskningsprosjekt “Menn som leser”, initiert i 2005. Resultatene fra prosjektet er formidlet i artikkelen "Dette er noe jeg har hatt bare for meg sjøl - om menn lesing og litteraturinteresse", Smidt 2010, foreløpig upublisert. Dette og de følgende sitatene fra mine resepsjonsundersøkelser er noe forkortet for å passe inn i denne artikkelens format.
} 
er altså ikke utelukkende resepsjonen av litterære verk Mukařovský behandler, selv om disse spiller en viktig rolle. Det kan det være greit å ha in mente i møte med Mukařovskýs terminologi, spesielt begrepene "tegn” og “ting” som jeg skal komme tilbake til. Det er også verd å legge merke til at dette er ett av de mange steder der Mukařovský kritiserer formalistenes abstrakte strukturtenkning.

"Intentionality and Unintentionality in Art” griper fatt i spørsmålet om intensjon i kulturytringer ${ }^{15}$. En teksts intensjon kan ikke fastlegges med utgangspunkt i forfatteren, verken dennes erfaringer eller psykologi, sier Mukařovský, et standpunkt som siden har blitt bredt akseptert. Spørsmålet må besvares med utgangspunkt i betrakteren eller leseren. Mukařovský bestemmer intensjonaliteten som en "lesning", en aktiv, sammenbindende bestrebelse. Det er ikke bare verkets opphavsmann som er aktiv:

The perceiver, too, is active vis-à- vis the work. The semantic unification that he reaches during perception is, of course, evoked to a greater or lesser degree by the organization of the work. It is not, however, limited to pure perception, but rather it has the nature of an effort by means of which the interrelations among the individual components of the perceived work are bound together. (Mukařovský 1943/1977a: 98).

Intensjonalitet er den kraften som binder tekstens deler sammen til en helhet som gir ytringen dets mening, sier Mukařovský. Utgangspunktet for denne forståelses-søkende bevegelsen gjennom teksten, er ytringens “semantiske energi” eller “ semantiske gest” (Mukařovský 1943/1977a: 96). Intensjonaliteten er i Mukařovskýs terminologi altså den meningsskapende prosessen, forståelsesprosessen, og omfatter både det som er sagt og måten det er sagt på. Først når teksten er lest til ende, kan man snakke om mening, som i Mukařovskýs terminologi er noe mer omfattende enn tolkningen og verkets idé ${ }^{16}$.

Intensjonalitet er altså leserens helhetsforståelse, det er leserens eller betrakterens samlede opplevelse av hva teksten uttrykker ${ }^{17}$. Dette er én viktig side av resepsjonen. Men leseprosessen har også en annen side. Alt det som ikke inngår i en slik helhetsforståelse, at "det er dette teksten uttrykker”, unnslipper så å si intensjonaliteten, den meningssøkende kraften. Dette andre, man kan kalle det et medklingende utenfor-område, hvis man vil, kaller Mukařovský "ikkeintensjonalitet”. Ikke-intensjonaliteten er alt det som betrakteren eller leseren ikke oppfatter som omfattet av en kommuniserende vilje, så å si. Det er ikke på samme måte som intensjonalitet en samlet størrelse. Ikke-intensjonalitet betegner flere ulike fenomen som har det til felles at de ikke er integrert i leserens opplevelse av teksten som helhetlig kommunikasjon og ytring.

Ikke-intensjonalitet er for det første elementer i teksten som leseren får problemer med å integrere i sin helhetsopplevelse. Det kan selvfølgelig skyldes at den er uklar og dårlig bearbeidet. Men det kan også skyldes at den er gåtefull, eller at leseren mangler den forforståelse som teksten forutsetter - at den impliserer kjennskap til et univers leseren ikke er fortrolig med.

\footnotetext{
${ }^{15}$ Det er verd å legge merke til at selv om Mukařovský i denne artikkelen eksplisitt setter søkelyset på kunsten, har teorien om intensjonalitet gyldighet også for andre typer tekster.

${ }^{16}$ I beskrivelsen av denne aktive relasjonen til teksten, legger Mukařovský seg nær opp til hermeneutikkens syn på forståelse, samtidig som hans tegn-begrep har klare paralleller i Bakhtins bestemmelse av ytringen. I Mukařovskýs senere forfatterskap bruker han da også hyppig betegnelsen ytring nærmest synonymt med tegn.

${ }^{17}$ Dette må ikke forstås dit hen at Mukařovský reduserer tekstens meningspotensiale til leserens forståelse, se eksempelvis Mukařovský 1943/1977a: 111 og Mukařovský 1946/1978: 112. Spørsmålet behandles senere i artikkelen.
} 
Eller at teksten bryter med en etablert litterær norm. Slike utfordringer eller brudd kan føre leseren ut på en søken etter en annen semantisk sammenheng, ofte mindre selvfølgelig for leseren enn den første, noe som kan føre til en opplevelse av fornyet innsikt, og dermed forhøyet glede, eller med andre ord: en intensivert estetisk opplevelse. Igjen: intensjonalitet er en prosess. Det som i første omgang oppleves som ikke-intensjonalt, kan i neste omgang integreres i intensjonaliteten.

Men slike brudd kan også føre til at leseren underkjenner tekstens kvalitet. Som vi vet, er det å lese en tekst som utfordrer ens forståelse en treningssak, som utvikles blant annet gjennom studier av litteratur. Men det er også en personlighetsmessig utfordring. Lesere har ulik grad av toleranse overfor tekster som stiller sammenhengsskapingen på prøve. Det er også interessant å konstatere hvordan opplevelsen av ikke-intensjonalitet gjerne fører leserens oppmerksomhet ut av teksten og hen på forfatteren, i et: "hva kan han ha ment?” Hvis leseren ikke finner et svar i teksten (intensjonalitet), kan det gi, ikke bare en negativ vurdering av verket, men også gå ut over forfatterens ethos ${ }^{18}$, slik som i følgende utsagn fra en meget litteraturinteressert godt voksen kvinne som har lest Kapten Nemos bibliotek av Per Olov Enquist:

Hvorfor i all verden skal man gjøre det så komplisert for leseren? Hvorfor i all verden skal du gjøre det på den måten? For jeg mener, han har jo evnen til å fortelle. Enquist, det er jo en av de fineste forfatterne vi har, så han kunne også fortalt det på en annen måte [...] Det irriterer meg noen ganger at formen blir mer betydningsfull enn selve fortellingen (Smidt 2002: 236).

Men Mukařovskýs begrep ikke-intensjonalitet er ikke ferdig utdypet med dette. Det som blir liggende utenfor intensjonaliteten omfatter også et helt annet fenomen: den oppslukte lesning. Dette blir underkommunisert i Eggens oversettelse av "Intentionality", fordi et vesentlig eksempel er utelatt (se Eggens oversettelse i Moderne litteraturteori 1991: 38 og Mukařovský 1943/1977a: 102). Det er imidlertid en viktig del av Mukařovskýs teoridannelse, ikke minst fordi han her beskriver en lesemåte som andre retninger i resepsjonsestetikken i liten grad har beskjeftiget seg med.

Den form for ikke-intensjonalitet som vi diskuterer her, kaller Mukařovský "en umiddelbart opplevende holdning” og "tilskuerens ${ }^{19}$ evne til å oppleve et kunstnerisk uttrykk som umediert virkelighet” (Mukařovský 1943/1977a: 102 og 103). Leseren glemmer at det han leser eller opplever er en ytring, og lever seg inn i fiktive personers skjebne og følelsesliv, han lever med i det litterære univers som om det virkelig utfoldet seg foran hans egne øyne. Denne forflytningen, som så å si gjør verket til en del av leserens liv, ligger utenfor intensjonaliteten, ja, verket opphører for en stund å være "tegn” (altså "sagt”), og blir i stedet "ikke-intensjonal” virkelighet (Mukařovský 1943/1977a: 103). Mukařovský benevner oppfattelsen av teksten som ikke-intensjonal eller umediert virkelighet for "ting" ${ }^{20}$, en betegnelse som snarere bringer tanken

\footnotetext{
${ }^{18}$ I leserundersøkelser blir det i blant tydelig at forfatterens ethos har betydning for leserens toleranse overfor utfordringer og fremmedhet i teksten. Har forfatteren høy status i miljøet, vil også leserens vilje til å søke en forståelse gjerne øke.

${ }^{19}$ Eksempelet er hentet fra teateret, en usedvanlig velegnet kunstart for å illustrere denne formen for kunstopplevelse, mener Mukařovský, fordi den nettopp spiller på illusjonen av levd liv.

${ }^{20}$ Et opplysende sitat står å lese på s 128 i Mukařovský 1943/1977a: "If the work of art is understood only as a sign, it is deprived of its direct incorporation into reality. It is not only a sign but also a thing immediately affecting man's mental life, causing direct and spontaneous involvement and penetrating through its action to the deepest level of the
} 
hen på skulptur og bildekunst, og kan virke overraskende, anvendt på språklige tekster. Men her må man ha in mente at Mukařovský har ambisjoner om å formulere en estetikk som er gyldig for alle slags kunstuttrykk. Poenget er at betrakteren både kan oppleve ytringen som ting og tegn, "[...] simultaneously as a thing and experience immediate feelings deriving from the impact of a non-semiotic reality as well as "aesthetic" feelings (i.e. feelings linked to the sign)" (109). Begrepet ikke-intensjonalitet skal altså også dekke den litterære teksten opplevd som virkelig liv. En slik lesemåte, “to get carried away" (sic. 103) ${ }^{21}$, betraktes ofte som naiv og primitiv, men det vil være elementer av en slik umiddelbart opplevende holdning også i lesninger som fokuserer på kunstnerisk intensjonalitet, mener Mukařovský. Slik bygger Mukařovský bro mellom en distansert og en innlevende lesemåte og forklarer hvordan leseren eller betrakteren kan oppleve teksten som noe som intenst angår ham: “[...] unintentionality incorporates the work of art into the sphere of the perceiver's existential interests and endows the work of art with an urgency unattainable by a pure sign [...]" (122).

I intervjuer med lesere er det svært ofte denne typen leseropplevelser man får beskrevet, og den er ofte høyt verdsatt av leseren selv. Mange lesere søker bevisst denne opplevelsen, og det er en lesemåte som gjerne tegner klare skiller mellom den skolerte og uskolerte leser. $\AA$ studere litteratur, er blant annet å lære å lese litterære tekster som “tegn”, som intensjonale, og ikke som “umediert virkelighet”. Fordi den oppslukte lesemåten er høyt verdsatt blant store publikumsgrupper, vil den også avtegne seg i tydelige sosiale distinksjoner. Jeg finner i mine leserundersøkelser (Smidt 2002 og 2010) ikke sjelden en uttalt skepsis til "akademiske” lesemåter blant lesere som ikke har et vitenskapelig skolert forhold til litteratur, og da er det gjerne akademikerens undervurdering av en oppslukt lesning det siktes til.

Ikke-intensjonalitet i form av oppslukt lesning må imidlertid også betraktes som del av en prosess. Mukařovský beskriver hvordan leseren kan gå inn og ut av en slik "medreisende” lesning, slik at det som i én fase av forståelsesprosessen blir liggende utenfor helhetsoppfatningen, i en annen fase integreres i intensjonaliteten. Opplevelsen av umiddelbart nærvær blir en del av forståelsen av ytringens helhet, og vil kunne bidra til å høyne opplevelsen av verkets verdi - for den aktuelle leseren.

\section{Estetisk verdi som sosialt fenomen}

Dermed kan det være naturlig å bevege seg over på et nytt aspekt: Mukařovskýs behandling av vurdering og estetisk verdi. Her må vi igjen gå tilbake til Aesthetic Function, Norm and Value as Sosial Facts fra 1936. Mukařovský foretar ikke noen direkte kobling til denne avhandlingen i artikkelen om intensjonalitet, men sammenhengene er åpenbare. Forskjellen er at forståelsesprosessen her ses i lys av vurderingsspørsmålet, og ikke i forhold til spørsmålet om intensjon. Beteg-

perceiver's personality. It is precisely as a thing that the work is capable of affecting what is universally human in man, whereas in its semiotic aspect the work always appeals eventually to what is socially and temporally determined in him.” Det kan betraktes som problematisk at Mukařovský bruker det same begrepet (ikkeintensjonalitet) om bruddet på helhetsforståelsen og den innlevende lesemåten, men poenget er at begge lesemåter fører bort fra opplevelsen av teksten som omfattet av en kommuniserende vilje.

${ }^{21}$ Mukařovský bruker også uttrykket "Mitreissung”, utlagt som “[an] immediate transport, which renders the work a direct part of the viewer's life” (op.cit. 103). 
nelsen “estetisk verdi” dekker hos Mukařovský leserens verdsetting av teksten som helhet, altså totaliteten slik den framstår i leserens bevissthet. Estetisk verdi er ikke en mekanisk samling av elementer, og det er heller ikke en tilstand. Det er en utfordring som møter leseren, og derfor en aktivitet og en prosess på linje med intensjonaliteten.

For litteratursosiologien er variasjonene i litterær vurdering av spesiell interesse. Vurderinger må nødvendigvis variere fordi det estetiske objektet (det “sansede” eller “leste” objektet) jo ikke er stabilt. Teksten blir betraktet i lys av ulike erfaringer, i lys av ulike verdiunivers, og i lys av ulike litterære tradisjoner. Verket er et kulturelt forankret tegn, rettet mot andre mennesker som medlemmer av et organisert kollektiv, ikke blott og bart artsvesener, argumenterer Mukařovský. Derfor kan vi heller ikke unnslippe den litterære ytringens sosiale karakter. Litteraturhistorien er full av konkrete eksempler på variasjon i vurderingen av tekster og forfatterskap. Institusjonene som setter standarden springer også ut av bestemte sosialhistoriske forhold. Estetisk verdi er en prosess som er avhengig både av utviklingen innenfor kunstfeltet og forandringer i det sosiale livet (Mukařovský 1936/1970: 67). Å undersøke disse sammenhengene bør være en egen oppgave for kunstsosiologien, sier Mukařovský.

I likhet med Bakhtin-skolen (se for eksempel Bakhtin 1979/1998: 27ff. og Volosjinov 1929/1996: 10ff.) peker Mukařovský på at en ytring er gjennomsyret av verdier. Også de ikkeestetiske funksjoner og verdier inngår i vurderingen av den litterære teksten (Mukařovský 1936/1970: 60), jf. utsagn som: “det var en meget velskrevet bok”, vs. “det var en viktig bok”. En kvinne forteller om sin leseropplevelse - igjen er det Kapten Nemos bibliotek av Per Olov Enquist det gjelder:

Når du spør om det var noe som gjorde spesielt inntrykk, så synes jeg hver eneste setning var så viktig og gjorde inntrykk på meg. Det var altså så gjennomgripende! Viktig bok! Han sier sannheter og kloke ting over alt! Jeg syns barnevernet skulle lese den. Folk på psykiatrisk poliklinikk for barn og all ting! (Smidt 2002: 243).

Moralske og politiske så vel som estetiske verdier får uttrykk i teksten. I leseprosessen møter disse leserens erfaringsverden og verdiunivers, og dette møtet danner basis for leserens vurdering av teksten og bestemmelsen av dens verdi.

Mukařovský mener at avhengigheten av leserens erfaringsbakgrunn og verdiunivers intensiveres i skjønnlitteraturen fordi den fiktive teksten, i motsetning til sakprosateksten, ikke henviser til en faktisk verden som kan verifisere dets virkelighetsbeskrivelse. Det skjønnlitterære verket er henvist til å finne sitt korrelat i leserens erfaring. Det er denne indirekte virkelighetsforankringen Mukařovský sikter til når han omtaler det litterære verket som autonomt (se Mukařovský 1936/1970: 90 og Mukařovský 1943/1977a: 124).

Det er verd å merke seg at Mukařovský bruker begrepet autonomi på en særegen måte. Innenfor nykritikken inngikk autonomi-begrepet i et oppgjør med den historisk-biografiske skolen og en understrekning av kunstens tidløse og allmennmenneskelige karakter. For den russiske formalismen pekte begrepet på kunsten som et avgrenset område med bestemte kjennetegn . Skjønnlitteraturen kjennetegnes ved litterariteten, ved at språket brukes på en spesiell måte, som avautomatiserer den dagligdagse persepsjonen av ting og fenomen. Bourdieu bruker autonomibegrepet til å beskrive kunst-feltets historisk skapte og relative selvstendighet fra den økonomiske, politiske og religiøse makten. Hos Mukařovský betegner autonomi noe fjerde; nemlig at teksten, lest som et kunstnerisk uttrykk, løsnes fra sin umiddelbare 
virkelighetsreferanse og i stedet refererer til virkeligheten indirekte, gjennom leserens erfaring. Slik etablerer han et skille mellom sakprosa og skjønnlitteratur ${ }^{22}$. Via denne prosessen kan man si at båndet til virkeligheten i en forstand svekkes, i en annen forstand styrkes:

It is weakened in the sense that the work does not refer to the reality which it directly depicts, and strengthened in that the work of art as a sign acquires a direct (figurative) tie with realities which are vitally important to the perceiver, and through them to the entire universe of the perceiver as a collection of values. Thus the work of art acquires the ability to refer to a reality which is totally different from the one which it depicts, and to systems of values other than the one from which it arose and on which it is founded. (Mukařovský 1936/1970: 75)

I vanlig kommunikasjon er relasjonen til den ytre virkeligheten sentral, i poetisk kommunikasjon er relasjonen til leserens erfaringsunivers sentral. Som eksempel nevner Mukařovský hvordan ekspressivt språk i vanlig kommunikasjon forteller om talerens følelsestilstand, mens ekspressivt språk i diktningen på en annen måte er bundet til betydningshelheten og blir et kunstnerisk virkemiddel. Dette innebærer på ingen måte at verket mister sin forbindelse med den ytre verden.

Igjen kan det være interessant å påpeke hvordan Mukařovský nærmer seg Bakhtins syn på leseprosessen som dialog ${ }^{23}$. Når et verk engasjerer, er det tegn på at det knytter an til et omfattende område av realiteter som er aktuelle og vitalt viktige for leseren. Dette forholdet utgjør et interessant felt i empiriske resepsjonsstudier. La meg gi et eksempel: to godt voksne kvinner, begge bibliotekarer, leser Gressdanseren, en magisk-realistisk roman av Susan Power. Den ene verdsetter den høyt og gir uttrykk for at den har gitt henne en stor leseropplevelse. Hun knytter den direkte til en personlig livshistorie og forestillingen om at det finnes krefter i tilværelsen som ikke kan forklares rasjonelt. Den andre finner den uinteressant og irriterende. Hun mener at den blir kommersiell og spekulativ ved at den spiller på populære nyreligiøse strømninger (Smidt 2002: 220-221). Den intensjonalitet og den totalvurdering disse to leserne kommer fram til, er avgjørende preget av møtet mellom leserens og romanens verdiverden. For resepsjonsforskeren blir forståelsene en inngang til lesernes verdiunivers.

Men betyr ikke dette at vi havner i estetisk subjektivisme? Nei, mener Mukařovský; verket er et tegn, og derfor et sosialt fenomen. Individets forhold til virkeligheten er aldri eksklusiv og unik, men formet av sosiale relasjoner. Språket, sjangrene og verdiene er noe kollektivt, forankret i et felles normsystem. Samfunnet oppretter også institusjonene som setter standarden og bidrar til å stabilisere vurderingsgrunnlaget på de ulike kunstområdene (Mukařovský 1936/1970: 83). Innenfor en slik forståelse blir litterær verdi et fenomen som ikke kan påvises utvetydig, men som det kan argumenteres for.

\section{Estetisk behag og ubehag}

Estetisk verdi (forstått som en meningsskapende, evaluerende lesning) setter altså tekstens mangfold av ikke-estetiske verdier i direkte kontakt (dialog) med leserens verdi- og erfaringsverden

\footnotetext{
22 Johan Tønnesson tar opp denne distinksjonen i sin sakprosadefinisjon i Hva er sakprosa (Tønnesson 2008). Mukařovský knytter altså dette til en lesemåte. Men som mangletreet både kan ha en redskapsfunksjon og en estetisk funksjon, kan også tekster tillegges en sterkere eller svakere informerende eller estetisk funksjon.

${ }^{23}$ Spørsmålet er behandlet mer utførlig i Smidt 2002: 19 ff.
} 
(Mukařovský 1936/1970: 89). Men her vil det aldri være fullstendig sammenfall, påpeker Mukařovský. Verdimessige spenninger og forventningsbrudd inngår i den estetiske verdi. Estetisk verdi omfatter ikke bare behag, men også utfordring og ubehag: "Fulfilling the norm causes aesthetic pleasure; aesthetic value must, however, include, in addition to pleasure, strong elements of displeasure [...]" (Mukařovský 1936/1970: 60). Spørsmålet blir hvordan man skal forstå slike formuleringer. Befinner Mukařovský seg her på linje med Sjklovskijs begrep om underliggjøring og formalistenes brudd-estetikk? For å svare på det spørsmålet må vi gå tilbake til Mukařovskýs funksjonsbegrep, som er selve navet i hans estetikk. På den første siden i Aesthetic Function, Norm and Value as Social Facts slår han fast:

There are no objects or actions which, by virtue of their essence or organization would, regardless of time, place or the person evaluating them, possess an aesthetic function and others which, again by their very nature, would be necessarily immune to the aesthetic function. (Mukařovský 1936/1970: 1)

På s. 28 i samme verk slås det fast: “aesthetic potential is not inherent in an object”. Det er altså ikke snakk om en egen poetisk funksjon i språket, som når den anvendes gir teksten egenskaper som gjør at den utvetydig kan bestemmes som kunst.

Men hva ligger det så i formuleringen om at estetisk verdi må inkludere både behag og ubehag? Sitatet er hentet fra innledningen til kapitlet om estetisk verdi, og inngår i en argumentasjon for at det ikke er tilstrekkelig å analysere den estetiske norm hvis man skal forstå hva estetisk verdi er. Å oppfylle den estetiske norm, skaper behag, skriver Mukařovský, men skal man forstå hva estetisk verdi er, må også "elements of displeasure" ${ }^{24}$ tas med i betraktningen. Konteksten gir en pekepinn om at det er begrepsavklaring, ikke et normativt utsagn det er snakk om. Begrepet estetisk verdi må bestemmes på en slik måte at det ikke bare omfatter nytelse, men også det ubehag som kan vekkes i leseprosessen (jf. ikke-intensjonalitet).

Nettopp fordi Mukařovský er opptatt av mottagelsen av kulturuttrykk i ulike sosiale grupperinger, beskriver han opplevelsen av ubehag, fremmedhet og ikke-intensjonalitet som relativt til betrakterens forforståelse (presuppositions, Mukařovský 1936/1970: 28). Hva som forstyrrer eller ikke forstyrrer er avhengig av øynene som ser, av leserens livserfaring og estetiske erfaring. Det som oppfattes som fremmed, som brudd, oppfattes slik på bakgrunn av en estetisk norm og tradisjon som leseren er fortrolig med.

Mukařovskýs prosjekt er å vise hvordan og hvorfor den litterære vurderingen varierer, hvor sammensatt grunnlaget for vurderingen er. I drøftingen av litterær verdi, tar han utgangspunkt i resepsjonen, ikke det materielle kunstobjektet. Som han sier i artikkelen "Can There Be a Universal Aesthetic Value in Art”:

In judging a work of art, we are not evaluating the material product itself, but the "aesthetic object" that is its immaterial equivalent in our consciousness[...] (Mukařovský 1939/1977a: 62)

Når Sjklovskij skriver om “underliggjøring”, tar han kunsttradisjonen og de litterære normene for gitt, og resonnerer ut fra den skolerte lesers forståelse. Det samme gjør Wolfgang Iser i sitt resonnement omkring tekstens tomrom. Den offentlige litteraturkritikken har selvfølgelig behov for å

\footnotetext{
24 “Displeasure" skal her ikke forstås bare i betydningen ubehag, men også som forstyrrelse av en umiddelbart nytende holdning. Det framgår av konteksten at betegnelsen dekker opplevelser av brudd på normen, avautomatisering og fremmedgjøring, forstyrrelse av den helhetssøkende prosess.
} 
etablere et fast grunnlag for vurdering, og må til en viss grad forutsette fortrolighet med en aktuell litterær tradisjon. Mukařovský, derimot, spør: tomrom og fremmedhet for hvem? Det er blant annet slik hans gjennomførte litteratursosiologiske perspektiv kommer til uttrykk.

Men spørsmålet om behag og forstyrrelse er ikke ferdig utdypet med dette. La oss se på følgende sitat:

If the task faced by the viewer is too simple, that is, if in a given situation similarities outweigh differences, the effect of the work is weakened and it quickly fades away, since the work does not force the viewer to remain or return. Therefore a work having weakly based dynamics rapidly becomes automatic. If, conversely, discovering the unity ${ }^{25}$ in the work is too difficult for the viewer, i.e. if the differences outnumber the similarities too greatly, it may happen that the viewer will not be able to comprehend the work as a deliberate construct. (Mukařovský 1936/1970: 92).

De likheter og forskjeller det her refereres til, gjelder spenningsforholdet mellom leserens erfarings- og verdiunivers på den ene siden og verkets univers på den andre. Det synes å ligge i Mukařovskýs resonnement at det som ikke på en eller annen måte utfordrer den dagligdagse persepsjon heller ikke vil få varig estetisk verdi. At perspektiv og betraktningsmåte varierer sosialt og historisk, rokker ikke ved en slik grunnleggende persepsjonspsykologisk mekanisme. Resonnementet nærmer seg et synspunkt som går ut på at det kulturuttrykket som vil behage for enhver pris og så mange som mulig, mangler en egen stemme. Det har ikke noe eget å bidra med.

Man kan si at Mukařovský er på linje med Sjklovskij ${ }^{26}$ når han sier at den teksten som ikke konfronterer betrakteren med noen utfordringer, som altså passerer raskt og uten motstand, vil svekkes i sin virkning. Teksten som er for vanskelig, vil heller ikke ha noen virkning. Men for få hindringer setter likevel tekstens varige effekt i større fare enn for store utfordringer, ettersom vanskeligheter kan overvinnes gjennom større kunnskap eller dypere kjennskap. Likevel er det ikke til å komme bort fra at Mukařovský relativiserer hindring, utfordring og brudd til leserens kulturelle forforståelse. For resepsjonsforskningen er dette et interessant studieområde.

Dette må imidlertid ikke forstås dit hen at Mukařovský er uinteressert i spørsmålet om tekstens iboende kvaliteter. Spørsmålet drøftes mot slutten i Aesthetic Function, Norm and Value as Social Facts, og på nytt i artikkelen "Can There Be a Universal Aesthetic Value in Art” fra 1939. "Universell estetisk verdi” bestemmes her som egenskaper ved artefakten, det materielle uttrykket, som igjen og igjen kan generere positive verdidommer. Med utgangspunkt i kunst- og litteraturhistorien, konstaterer Mukařovský at verkets verdi ikke kan betraktes som noen konstant størrelse. Varig verdi må forstås som en levende energi som for å forbli aktiv stadig må fornyes: “Universal value is in a state of constant genesis” (Mukařovský 1939/1977a: 68, se også 60). Men noen verk kan opprettholde en meget høy vurdering over lang tid. Fins det da ikke likevel iboende kvaliteter i artefakten som borger for en slik høy verdsetting i ulike miljø til ulike tider? På dette spørsmålet svarer Mukařovský bekreftende. Et maleri, et musikkstykke eller et litterært verk kan gis en meget høy verdi i en bestemt historisk situasjon, men det kan også vise seg å ha en verdi som opprettholdes over lang tid. Det kan med andre ord ha kapasitet til å fungere som et estetisk verdifullt objekt i svært ulike sosiale og historiske miljø (Mukařovský 1939/1977a: 66).

\footnotetext{
25 “unity” refererer her til leserens forståelse, altså intensjonaliteten. I innledningen til sitatet heter det: “unity should not be understood as something static, as complete harmony, but as dynamic, as a problem with which the work confronts the viewer." (Mukařovský 1936/1970: 91).

${ }^{26}$ Noe han selv påpeker, se Mukařovský 1936/1970: 91-92.
} 
Vi har sett at Mukařovský understreker at det nødvendigvis er det estetiske objektet, ikke det materielle produktet vi vurderer når vi feller en verdidom (62). Estetisk verdi er likevel uomgjengelig bundet til den materielle artefakten, resonnerer Mukařovský. Men fordi den materielle artefakten er et tegn, er det en spesiell type bånd det er snakk om. Hvordan kan tegnet stadig fornyes, og likevel opprettholde sin verdi?

På dette spørsmålet har Mukařovský et todelt svar. Det ene aspektet peker på at jo større semantisk kapasitet en tekst har, jo større er potensialet for varig verdi (Mukařovský 1939/1977a: 66). Språklig mangfold, variasjon og innsikt er potensielle estetiske tilganger. Muligheten for å komme i dialog med ulike erfaringsverdener blir større. Det andre aspektet er forbindelsen til en fellesmenneskelig basis. Verket som kan opprettholde sin semantiske rikdom over tid knyter an til noe grunnleggende menneskelig. Men hvordan dette skjer, kan ikke fastslås. "Art will always continue to reach the anthropological basis through new paths not yet travelled" (Mukařovský 1939/1977a: 67) ${ }^{27}$.

\section{Mukařovský og Bakhtin}

Jeg har flere ganger vært inne på at Mukařovský, gjennom sin vektlegging av den aktive leseren eller betrakteren, nærmer seg Bakhtins språk- og litteraturforståelse. Sammenhengen mellom Mukařovský og Bakhtin har vært påpekt før, også i Moderne Litteraturteori (Kittang et. al.1991: 29 og 1993: 15, 100) men her igjen i en noe spesiell tapning. For her leses også Bakhtin som en videreføring av den russiske formalismen, ikke som et brudd med den. Dette er en lesning i tråd med den tidlige presentasjonen av Bakhtin for et vesteuropeisk publikum gjennom Tzvetan Todorovs og Julia Kristevas arbeider.

Men jeg vil mene at den nyere Bakhtin-forskningen og dens dypere forståelse av Bakhtins verk, gjør en slik Bakhtin-tolkning vanskelig å opprettholde. Rasmus Slaattelid påpeker at "Todorovs Bakhtin-fortolkning ncermar seg dei formalistiske tankebanane Bakhtin sjølv eksplisitt og gjentekne gonger tok avstand frå”, og kaller Kristevas lesning “ei “omsetjing” av Bakhtins translingvistikk til den franske strukturalismens og semiotikkens språk” (Slaattelid 1998: 53). I likhet med Slaattelid betrakter jeg Bakhtins språk- og kommunikasjonsteori som grunnleggende forskjellig fra den Saussure-inspirerte strukturalismen, og - for å vende tilbake til Mukařovský også Mukařovskýs senere arbeider som en overskridelse snarere enn en videreføring av formalismens og den tidlige strukturalismens språk- og kunstforståelse.

Mukařovský har åpenbart kjent til Bakhtinskolen, og henviser blant annet anerkjennende til Volosjinov $^{28}$ i essayet “On Poetic Language” fra 1940 (Mukařovský 1940/1977b: 50 og 59). I "Personality in Art” fra 1944, har han dessuten formuleringer som i høy grad minner om Bakhtinskolens syn:

\footnotetext{
${ }^{27}$ Det er selvfølgelig ingen motsetning mellom synet på mennesket som bærer av noe fellesmenneskelig og som sosialt vesen. Se også sitatet i note 16 .

${ }^{28}$ Jeg skal her ikke gå inn på diskusjonen i Bakhtin-litteraturen om hvorvidt Volosjinov eller Bakhtin er den egentlige forfatteren av Marxism and the Philosophy of Language (Volosjinov 1929/1996), men nøye meg med å plassere Volosjinov som del av Bakhtinskolen.
} 
We have basically equated the relationship between the artist and the perceiver to the relation between the addresser and the adressee. This equation is appropriate not only for them, but also for the work of art itself. An utterance can pass between speaker and listener because it is a sign which both parties understand. In making his utterance, the speaker takes into account in advance how the listener will understand him; he formulates it with regard to the listener. It is exactly the same with the work of art (Mukařovský 1944/1977a: 162)

Her er både ytringsbegrepet, ytringens adressivitet og den dialogiske relasjonen mellom "taler" og "lytter” i tråd med Bakhtins forståelse. Det kan derfor være av interesse å undersøke denne korrespondansen nærmere. En ekskurs til Bakhtins translingvistiske univers kan tydeliggjøre den posisjonen jeg hevder at Mukařovský er i ferd med å innta fra midten av 30-tallet og i realiteten har inntatt når han skriver sine sene artikler om dialog og personlighet i kunsten (Mukařovský 1940/1977b og 1944/1977a).

Det har vært sagt at Bakhtin til tross for sin vekt på dialogen og ytringen som et ledd i en kjede av tiltaler og svar, ikke har utarbeidet noen egentlig resepsjonsestetikk ${ }^{29}$. Dette er riktig for så vidt som han ikke behandler spørsmålet utførlig. Men hans bestemmelse av forståelsen som aktivt svarende og meningsskapende, må også gjelde lesningen av litteratur, enten det er sakprosa eller fiksjon. Dessuten er lesning og resepsjon av litterære tekster utallige ganger berørt, både i hans større avhandlinger og essays, men også mer fragmentarisk i hans sene artikler og notater.

Det første og mest opplagte momentet som må tas med i undersøkelsen av Bakhtins bidrag til resepsjonsteorien, er at hverdagsdialogen kan tjene som modell for andre former for kommunikasjon. Bakhtin polemiserer mot all språkteori som ikke tar den aktive lytteren med i betraktningen $^{30}$. Han definerer også den litterære teksten som en ytring, og som sådan inviterer det til et aktivt svar, en respons. Interaksjonen mellom tekst og leser har visse fundamentale trekk til felles med andre former for dialog. Bakhtin generaliserer: "Any understanding of live speech, $a$ live utterance, is inherently responsive [...]” (Bakhtin 1979/1996: 68), All forståelse er gjennomsyret av respons, selv om denne ikke artikuleres umiddelbart. Bakhtin snakker om "responsive understanding with delayed reaction”, og legger til:

In most cases, genres of complex cultural communication are intended precisely for this kind of actively responsive understanding with delayed action. Everything we have said here also pertains to written and read speech, with the appropriate adjustments and additions (Bakhtin 1979/1996: 68-69).

Det neste momentet som må bringes inn, er den svarende forståelsen som noe nytt og kvalitativt annet enn den opprinnelige ytringen (det litterære verket). Bakhtin betrakter ikke svaret i dialogen som en avkodning av en gitt mening, men som en aktiv stillingtagen til et verdiladet utsagn. Også lesningen, forstått som svar, er selv en ytring, enten den er tenkt eller talt, umiddelbar eller forsinket, og som ytring er den partisk, farget av leserens posisjon og perspektiv, verdier og verdensanskuelse $^{31}$.

\footnotetext{
29 Se Pearce 1994: 18, og dessuten Shepherd, David. Bakhtin and the Reader. - I: Hirschop, Ken (1991). Bakhtin and Cultural Theory / Hirschop, Ken and David Shepherd (ed.). - Manchester and New York : Manchester University Press. - s. 91.

${ }^{30}$ Se for eksempel Bakhtin 1979/1996: $67 \mathrm{ff}$.

${ }^{31}$ I notatene fra 1970-71 sier Bakhtin at forståelse alltid innbefatter en evaluering. Men utgangspunktet for evaluering kan endres i leseprosessen, i og med at både verket og leseren til en viss grad forandres i den
} 
Bakhtin understreker i mange sammenhenger at adressaten ikke er en abstrakt konstruksjon, men en levende "annen” som bringer med seg et bestemt ståsted og et repertoar av sosialt bestemte språk til dialogen. Det leste verket er altså ikke en aktualisering av et utvalg av gitte muligheter, slik Wolfgang Isers resepsjonsestetikk kan sies å hevde ${ }^{32}$, men tilføres noe annet og fremmed $^{33}$. Den leste teksten er et estetisk objekt som også omfatter den verdiladede konteksten som den leses i (Jf. Mukařovský 1936/1970). Konteksten omgir teksten som musikk, som skaper nye klanger i verket (Bakhtin 1979/1996: 166).

Bakhtins drøfting av det han kaller “den internt overtalende diskursen” 34 har relevans for forståelsen av det nye som skapes og tilføres verket i lesningen. Bakhtin behandler denne diskursen som utgangspunktet for en form for dobbelt-stemthet i romanen, men også som modell for møtet mellom tekst og leser. Han omtaler eksempelvis en annens ytrings påvirkning på en forfatter på følgende måte: "When such an influence is deep and productive, there is no external imitation, no simple reproduction, but rather a further creative development of another's (more precisely, half-other) discourse in a new context and under new conditions" (Bakhtin 1975/1998a: 347) ${ }^{35}$.

Oppsummert kan Bakhtins syn på resepsjonen formuleres slik: resepsjonen, mottagelsen av den litterære teksten, er ingen avkodning av en på forhånd gitt mening. Det er heller ikke blott og bart en aktualisering av et utvalg gitte muligheter, og det er ikke en projeksjon av leserens indre verden på et tegnsystem eller en tilpasning av teksten til et tolkningsfellesskap. Den kan heller ikke reduseres til en indikator på leserens smak og kulturelle kapital.

forståelsesprosessen som lesningen er. "From Notes Made in 1970-71" i Bakhtin 1979/1996: 142. Jf. Mukařovskýs bestemmelse av intensjonalitet og verdi som dynamisk.

${ }^{32}$ Se min kritikk av Wolfgang Isers resepsjonsestetikk i Smidt, Jofrid Karner (1999). En kritisk lesning av Wolfgang Isers resepsjonsestetikk. - I: Tekstblikk: rapport fra forskersymposium i nordisk nettverk for tekst- og

litteraturpedagogikk. Redigert av Elise Seip Tønnessen og Eva Maagerø. - TemaNord 1999: 585

${ }^{33}$ I utkastet "Methodology for the human sciences" kritiserer Bakhtin konseptet "den immanente" eller "ideelle" leser fordi det kan gi en illusjon om å representere noe annet enn forfatterens taleplan. Men en slik "leser” "[..] cannot introduce anything of his own, anything new, into the ideally understood work or into the ideally complete plan of the author. He is in the same time and space as the author or, rather, like the author he is outside time and space (as is any abstract ideal formulation), and therefore he cannot be an-other or the other for the author, he cannot have any surplus that is determined by his otherness" (Bakhtin 1979/1996: 165).

${ }^{34}$ Dette er min oversettelse av "internally persuasive discourse". Begrepet forklares i "Discourse in the Novel”, (Bakhtin 1975/1998a: 345 ff).

${ }^{35}$ Her kan det være relevant også å se nærmere på Volosjinovs behandling av "rapportert tale” ("Expositions of the Problem of Reported Speech" i Volosjinov 1996, s. 115-123). Rapportert tale bestemmes som "the active reception of other speakers' speech"(117) og "words reacting on words"(116). Det som beskrives her, er ikke en abstrakt framstilling av selve lese/lytte-prosessens elementer, men en beskrivelse av en faktisk leser/lytters resepsjon av en annens ytring. Følgende formulering kan virke klargjørende: "Everything vital in the evaluative reception of another's utterance, everything of any ideological value, is expressed in the material of inner speech. After all, it is not a mute, wordless creature that receives such an utterance, but a human being full of inner words. All his experiences - his so-called apperceptive background - exist encoded in his inner speech, and only to that extent do they come into contact with speech received from outside" (118). Det er åpenbart at Volosjinov ikke sikter mot en beskrivelse av resepsjonen av litterære verk, men mot analysen av rapportert tale i eksempelvis samtaler, i sakprosa og i romanen. Jeg mener likevel at betraktingsmåten har betydning for analysen av faktiske leseres respons på litterære verk, nettopp fordi en slik resepsjon kommer til uttrykk i ytringer som favner den litterære teksten som den andres tale. 
Resepsjonen er et svar på det litterære verket som ytring, og som sådan er det en ny (dobbelt-stemt) ytring. Denne svarende ytringen kan på linje med det litterære verket gjøres til gjenstand for analyse. En slik analyse vil gripe fatt i hvordan leseren gjennom sin svarende resepsjon posisjonerer seg i en faktisk sosial, ideologisk og historisk kontekst.

Slik jeg ser det er det først i lyset av en slik tolkning Mukařovskýs bestemmelse av intensjonalitet, funksjon, norm og verdi faller på plass. Alle disse elementene utgjør aspekt ved en svarende forståelse.

Det har vært regnet som et problem at en vektlegging av leserens kreative håndtering av teksten kan føre til at teksten som original og egenartet ytring overses - at teksten så å si oppløser seg i et mangfold av forståelser, slik at man havner i total relativisme. Selv om enkelte readerresponse teoretikere kom farlig nær et slikt synspunkt, er ikke dette en nødvendig eller logisk konklusjon $^{36}$. Når resepsjonen betraktes som et svar, og analyseres som en selvstendig ytring, blir ikke den opprinnelige ytring av den grunn redusert til en slik lesemåte. Det dreier seg om to ulike ytringer som må analyseres hver for seg, på sine premisser. For å vende tilbake til Mukařovský er det dekning for å si at han både gir redskap til analyse av konkrete kulturuttrykk og til analyser av resepsjoner. En analyse av den litterære teksten har som mål å formulere fruktbare og bokstavelig talt forsvarlige tolkninger av det litterære verket. Resepsjonsforskeren, derimot, analyserer ulike lesninger (det vil si nye tekster, "svar" på den originale ytringen). For litteratursosiologien kan åpenbare feiltolkninger være like interessante som plausible tolkninger. Det betyr ikke at man underkjenner den litterære teksten som original ytring. I sin utforskning av den estetiske opplevelse går Mukařovský aldri bort fra at artefakten har et uttrykk som kan analyseres.

Bakhtin har igjen en interessant belysning av problemet. I Discourse in the Novel er han inne på at en lesning kan være mer eller mindre adekvat (Bakhtin 1975/1998a: 420). I notatene fra 1970-71 nevner han at det er en oppgave for forskningen å prøve å forstå verket slik forfatteren selv forsto det (Bakhtin 1979/1996: 144). En slik ambisjon er i tråd med betraktningen av ytringen som originalt formet og som uttrykk for en posisjon og et perspektiv, en taleplan (for eksempel en kunstnerisk ambisjon) og et sett verdier.

Det nye som en lesning i en ny kontekst kan avstedkomme kaller Bakhtin for en "reaksentuering”37. Bakhtin er ikke fremmed for tanken at en slik ny-lesning kan forvrenge eller forenkle verket, men er mer opptatt av den kreative fornyelse den nye konteksten kan gi grobunn for. At klassiske verk lever, skyldes nettopp en sosial og ideologisk re-aksentuering, mener han: "Thanks to the intentional potential embedded in them, such works have proved capable of uncovering in each era and against ever new dialogizing backgrounds ever newer aspects of meaning; their semantic content literally continues to grow, to further create out of itself." $(421)^{38}$. Det er et slikt dobbeltblikk jeg mener å finne også i Mukařovskýs estetikk.

\footnotetext{
${ }^{36}$ Stanley Fish gikk seg fast i en slik forståelse. Problemet får for øvrig sin belysning i den berømte diskusjonen mellom Richard Rorty og Umberto Eco, se Eco 1992.

${ }^{37}$ Min framstilling av dette begrepet bygger på det avsluttende resonnementet i “Discourse in the Novel”, Bakhtin 1975/1998a, s. 419-422.

38 Synspunktet utvikles videre i en langt senere tekst, “Response to a Question from Novy Mir”, skrevet i 1970. Her slår Bakhtin fast at det er nødvendig å studere litteraturen i sin opprinnelige kulturelle kontekst. En vitenskapelig analyse av eldre litterære verk forutsetter en grundig kjennskap til tidens kulturelle landskap. Men dette er ikke nok: "Trying to understand and explain a work solely in terms of the conditions of its epoch alone, solely in terms of the
} 
Det er ingen tvil om at Mukařovskýs omtale av resepsjonens dialogiske karakter virker prøvende og uferdig i forhold til den avgjørende plass dette har i Bakhtinskolens litteratur- og språkteori. At hans analyser av det dialogiske i ytringen og i resepsjonen er uferdige, er imidlertid noe Mukařovský selv er klar over og kommenterer i de avsluttende avsnittene i artikkelen "On Poetic Language”. Her konstaterer han samtidig at det formalistiske stadiet er endelig tilbakelagt, og at "the discovery of the semantic dynamics and its opposition to semantic statics has brought meaning closer to the dynamics of psychic processes.” (Mukařovský 1940/1977b: 63). Det var nettopp oppdagelsen av den dynamiske semantikk (i motsetning til formalismens statiske) Mukařovský tilskrev Volosjinov tidligere i artikkelen.

\section{Estetikk, strukturalisme og litteratursosiologi}

I 1934 skriver Mukařovský en introduksjon og kritikk av Sjklovskijs verk Theory of Prose, som på det tidspunktet har kommet i tsjekkisk oversettelse (Mukařovský 1934/1977b: 134 ff). Her forklarer han grunnlaget for Sjklovskijs polemiske og ensidige fokusering på diktverkets form, samtidig som han viser at litteraturvitenskapen har beveget seg et langt skritt videre etter at teksten ble utgitt første gang. Den eldre litteraturhistorien (Mukařovský sikter her til den historisk-biografiske skolen) gjorde den feilen at den la all vekt på ekstern påvirkning og ikke tok hensyn til teksten i seg selv. I sitt oppgjør med denne tilnærmingen gjorde formalismen på sin side den feilen at den "plasserte littercer aktivitet i et vakuum” (Mukařovský 1934/1977b: 140, min oversettelse). Nå, sier Mukařovský, har strukturalismen skapt en syntese av disse to: "Thus structuralism does not limit literary history only to an analysis of form, nor does it clash at all with sociological studies of literature” (141).

Når Mukařovský i 1946 skriver artikkelen “On Structuralism” beskriver han den enkelte kunstneriske ytring som en formet helhet, som i sin tur inngår i skiftende relasjoner til en tradisjon, som en lenke i en kjede av uttrykk. Slik blir selv det mest originale verket en del av " $a$ continuous stream passing through time” (Mukařovský 1946/1977a, jf. Bakhtins "kjede av ytringer” i Bakhtin 1979/1998). Den enkelte kunstart representerer også en struktur av relasjoner (verk og utøvere), der eksempelvis de etablerte utøverne påvirker nykommerne (og gjerne visa versa $)^{39}$. Kunstartene påvirker i sin tur hverandre, som nasjonallitteraturer også påvirker hverandre, ikke gjennom passive mottagere, men gjennom aktive aktører. Mukařovskýs strukturalisme er nå en resepsjonsteori.

Mukařovský kaller i Aesthetic Function, Norm and Value as Social Facts sin tilnærming til estetikken for "the sociology of aesthetics" (Mukařovský 1936/1970: 20). Denne "estetikkens sosiologi” undersøker litteraturens og andre estetiske fenomens betydninger og fremtredelsesformer i samfunnet. Man kan si at Mukařovský utarbeider en metodikk, der kulturytringenes vekslende funksjoner utgjør ett aspekt, endringsprosesser på de estetiske normenes område et

conditions of the most immediate time, will never enable us to penetrate into its semantic depths[...]”(Bakhtin 1979/1996: 4). Som en illustrasjon nevner Bakhtin hvordan Shakespeare har vokst, slik at vår Shakespeare ikke lenger kan presses tilbake i sin egen tid, men bærer med seg det andre epoker har funnet i verkene hans, og som verken han selv eller hans samtid hadde forutsetninger for å se.

${ }^{39}$ Bourdieu har tatt poenget inn i sin feltanalyse, se Bourdieu 1996. 
annet, grunnlaget for varierende estetisk vurdering et tredje og selve leseprosessens og leseopplevelsens dynamikk et fjerde område.

Spørsmålet om funksjon har vært et tilbakevendende problem i sosiologiske leserundersøkelser. Sven Møller Kristensen tumlet med problemet i sin artikkel om former for aksept (Kristensen 1970). Øystein Noreng nærmet seg en innsikt om litteraturens polyfunksjonalitet da han skrev om "den kritisk-underholdende innstillingen" som en dominerende lesemåte hos et norsk publikum (Noreng 1974). Bourdieu reserverte funksjonsbegrepet til nyttefunksjonene, og skrev om den rene smaken som en prioritering av form over funksjon. Men dermed går han glipp av den dynamikken som fins mellom den estetiske funksjon og andre funksjoner.

Undersøkelsen av estetiske normer i det litterære feltet og samfunnet for øvrig, og hvordan disse normene varierer og konkurrerer, er et interessant litteratursosiologisk forskningsområde. Tendensen til å isolere den estetiske norm fra andre normer i det litterære feltet, og den motsatte tendens til nettopp å blande estetiske og moralske normer som man kan finne i andre miljø (Mukařovský 1936/1970: 58), skaper markante sosiale grenseoppganger, og i blant opphetede kulturdebatter, som da Kjartan Slettemarks Vietnambilde ble utstilt på Stortingsplassen i 1965 og utsatt for hærverk ${ }^{40}$. Michele Lamont baserer sine perspektivrike studier av sosiale distinksjoner i USA og Frankrike blant annet på slike grenseoppganger (Lamont 1992).

Spesielt gir Mukařovský gode kategorier for analysen av resepsjonsdokument og leserintervjuer. Spillet mellom den meningssøkende og vurderende leseprosessen og den oppslukte opplevelsen, mellom den litterære ytringen og leserens erfaringsunivers, kan håndteres på en innsiktsgivende måte gjennom refleksjoner knyttet til intensjonaliteten og til funksjons-, normog verdibegrepene. Mukařovský kan dessuten gi et betydelig supplement til Bourdieu-inspirerte studier av posisjoner og maktforhold på kulturfeltet, da han berører spørsmål knyttet til det Bourdieu ville kalt sosiale disposisjoner og habitus. For Mukařovský er sosiologien en fundamental dimensjon i estetikken ${ }^{41}$. Som han sier i Aesthetic Function, Norm and Value as Social Facts (s. 70): “it is impossible to escape the social character of art”.

\section{Litteratur}

Asdal, Kristin et al. (2008). Tekst og historie: å lese tekster historisk. - Oslo: Universitetsforlaget

Aspelin, Kurt och Lundberg, B.A. (1971). Form och struktur: texter till en metodologisk tradition innom litteraturvetenskapen/valda av Kurt Aspelin och Bengt A. Lundberg. - Stockholm: PAN/Norstedts

Bakhtin, Mikhail M. (1979/1996). Speech genres and other late essays. - Austin: University of Texas Press. $-6^{\text {th }}$ paperback printing, cop. 1986

\footnotetext{
${ }^{40}$ Se Jan Erik Volds kommentar i Dikt og sak, Det Norske Studentersamfund/Universitetsforlaget 1967

${ }^{41}$ Se for eksempel følgende formulering i Aesthetic Function, Norm and Value as social Facts s 47: "Every social stratum, but also many environments (e.g. country - city), has its own aesthetic canon which is one of its most characteristic attributes. If, for example, an individual moves from a lower stratum to a higher one, he tries, as a rule, at least to find the superficial characteristics of the tastes of that stratum to which he wishes to belong (an aesthetically motivated change in clothing, housing, social behavior, etc.) Since, however, a change of real personal tastes is a very difficult operation, spontaneous taste becomes one of the most hazardous, although often concealed, aspects of his original stratum.”
} 
Bakhtin, Mikhail M. (1975/1998a). The dialogic imagination: four essays / by M.M.Bakhtin. - $11^{\text {th }}$ ed. - Austin: University of Texas Press. - Cop.1981. Opprinnelig utgitt i Moskva 1975 med tittelen Voprosy literatury i estetiki

Bakhtin, Mikhail M. (1975/1998a). Discourse in the novel. - I: The dialogic imagination: four essays / by M.M.Bakhtin. - $11^{\text {th }}$ ed. - Austin: University of Texas Press.

Bakhtin, Mikhail M. (1979/1998b). Spørsmålet om talegenrane / Mikhail M. Bakhtin; omsett og med etterord av Rasmus T. Slaattelid. - Bergen: Ariadne forlag. Opprinnelig utgitt i 1979

Berge, Kjell Lars (1990). Tekstnormers diakroni. - Stockholm: Meddelanden från Institutionen för nordiska språk vid Stockholms universitet MINS 33

Bourdieu, Pierre (1984). Distinction: a social critique of the judgement of taste. - London: Routledge \& Kegan Paul. - Originaltittel: La Distinction. Critique sociale du jugement, utgitt i 1979

Bourdieu, Pierre (1996). The rules of art: genesis and structure of the literary field. - Cambridge: Polity Press. Originaltittel: Les régles de l'art, utgitt i 1992

Dewey, John (1934/1958). Art as experience. - New York: Capricorn. - Først utkommet 1934

Eco, Umberto (1992). Interpretation and overinterpretation. - Cambridge: Cambridge University Press

Gadamer, Hans Georg (1977). Die Aktualität des Schönen: Kunst als Spiel, Symbol und Fest. - Stuttgart: Philipp Reclam

Galan, F.W. (1984). Historic Structures: the Prague School Project, 1928-1946. - Austin: University of Texas Press

Gammelgaard, Karen (2003a). Tekstens mening: en introduksjon til Pragerskolen. - Fredriksberg: Roskilde Universitetsforlag

Gammelgaard, Karen (2003b). Den skandinaviske reception af Pragerskolens litteraturvidenskab. I: Acta Universitatis Carolinae - Philologica 2, Germanistica Pragensia XVII, pag. 107-115

Heldal, Anders og Linneberg, Arild (red.) (1978) Strukturalisme i litteraturvitenskapen. - Oslo: Gyldendal

Iser, Wolfgang (1978). The act of reading: a theory of aesthetic response. - Baltimore: John Hopkins University Press

Jakobson, Roman (1960/1978). Lingvistikk og poetikk. - I: Heldal, Anders og Linneberg, Arild (red.) Strukturalisme i litteraturvitenskapen. - Oslo: Gyldendal

Kittang, Atle et. al. (1993). Moderne litteraturteori: en innføring. - Oslo: Universitetsforlaget

Kittang, Atle et. al. (red.) (1991). Moderne litteraturteori: en antologi. - Oslo: Universitetsforlaget

Kock, Christian (red.) (1971). Tjekkisk strukturalisme: en antologi ved Christian Kock. - København: Munksgaard

Kristensen, Sven Møller (1970). Litteratursociologiske essays. - København: Munksgaard

Lamont, Michèle (1992). Money, morals, and manners: the culture of the French and the American upper-middle class. - Chicago: University of Chicago Press 
Le Grand, Eva: Mukařovský, Jan. - I: Encyclopedia of contemporary literary theory (1993) / edited by Irena Makaryk. - Toronto: University of Toronto Press

Linneberg, Arild (1979). Arne Garborgs Haugtussa: en analyse av kunstverket I kommunikasjonen. - Oslo: Institutt for allmenn litteraturvitenskap, Universitetet i Oslo

Linneberg, Arild (1993). Historie og samfunn. - I: Kittang, Atle et. al. (1993). Moderne litteraturteori: en innføring. - Oslo: Universitetsforlaget

Mukařovský, Jan (1932/1964). Standard language and poetic language. - I: A Prague School reader on esthetics, literary structure, and style / selected and translated from the original Czech by Paul L. Garvin. - Georgetown : Georgetown University Press, 1964. - Opprinnelig utgitt i 1932

Mukařovský, Jan (1948/1964). The esthetics of language. - I: A Prague School reader on esthetics, literary structure, and style / selected and translated from the original Czech by Paul L. Garvin. - Georgetown : Georgetown University Press, 1964. - Opprinnelig utgitt i 1948

Mukařovský, Jan (1936/1970). Aesthetic function, norm and value as social facts. - Ann Arbor: Department of Slavic Language and Literature, University of Michigan. - Originaltittel: Estetiká funcke, norma a hodnota jako sociální fakty. - Opprinnelig utgitt i 1936

Mukařovský, Jan (1946/1971). To studier over det digteriske sprog. - I: Kock, Christian (red.) (1971). Tjekkisk strukturalisme: en antologi ved Christian Kock. - København: Munksgaard

Mukařovský, Jan (1977a). Structure, sign and function: selected essays / by Jan Mukařovský; translated and edited by John Burbank and Peter Steiner. - New Haven: Yale University Press

Mukařovský, Jan (1939/1977a). Can there be a universal aesthetic value in art? - I: Structure, sign and function: selected essays - New Haven: Yale University Press. - Opprinnelig utgitt i 1939

Mukařovský, Jan (1942/1977a). The place of the aesthetic function among the other functions. - I: Structure, sign and function: selected essays - New Haven: Yale University Press. - Opprinnelig utgitt i 1942

Mukařovský, Jan (1943/1977a). Intentionality and unintentionality in art. - I: Structure, sign and function: selected essays - New Haven: Yale University Press. - Opprinnelig foredrag i Prags lingvistiske krets 1943, senere publisert i Praha 1966 i artikkelsamlingen Studie Z estetiky

Mukařovský, Jan (1944/1977a). Personality in art. - I: Structure, sign and function: selected essays - New Haven: Yale University Press. - Opprinnelig utgitt i 1944

Mukařovský, Jan (1946/1977a). On structuralism. - I: Structure, sign and function: selected essays - New Haven: Yale University Press. - Opprinnelig utgitt i 1946

Mukařovský, Jan (1977b). The word and verbal art: selected essays by Jan Mukařovský. - New Haven: Yale University Press

Mukařovský, Jan (1934/1977b). A note on the Czech translation of Sklovskij’s Therory of Prose. - I: The word and verbal art: selected essays by Jan Mukařovský. - New Haven: Yale University Press. - Opprinnelig utgitt i 1934

Mukařovský, Jan (1938/1977b). Poetic designation and the aesthetic function of language. - I: The word and verbal art: selected essays by Jan Mukařovský. - New Haven: Yale University Press. - Opprinnelig utgitt i 1938 
Mukařovský, Jan (1940/1977b). On poetic language. - I: The word and verbal art: selected essays by Jan Mukařovský. - New Haven: Yale University Press - Opprinnelig utgitt I 1940. Foreligger også i dansk oversettelse: "Om det digteriske sprog” I: Kock, Christian (red.) (1971). Tjekkisk strukturalisme: en antologi ved Christian Kock. - København: Munksgaard

Mukařovský, Jan (1940/1977b). Dialogue and monologue. - I: The word and verbal art: selected essays by Jan Mukařovský. - New Haven: Yale University Press. - Opprinnelig utgitt I 1940

Mukařovský, Jan (1943-45/1977b). The individual and literary development. - I: The word and verbal art: selected essays by Jan Mukařovský. - New Haven: Yale University Press. - Opprinnelig et foredrag i Prags lingvistiske krets 1943-45, publisert i 1966

Mukařovský, Jan (1946/1977b). A note on semantics of the poetic image. - I: The word and verbal art: selected essays by Jan Mukařrovský. - New Haven: Yale University Press. - Opprinnelig utgitt i 1946

Mukařovský, Jan (1978). Estetisk verdi som sosialt faktum (med et sammendrag om estetisk funksjon og estetisk norm). - I: Heldal, A. og Linneberg , A. (red.) Strukturalisme i litteraturvitenskapen. - Oslo: Gyldendal. Opprinnelig utgitt i 1936

Mukařovský, Jan (1946/1978). Om det dikteriske bildets semantikk. - I: Heldal, A. og Linneberg , A. (red.) Strukturalisme i litteraturvitenskapen. - Oslo: Gyldendal. - Opprinnelig utgitt i 1946

Mukařovský, Jan (1943/1991). Intensjonalitet og ikke-intensjonalitet i kunsten. - I: Moderne litteraturteori: en antologi / ved Atle Kittang ... [et al.] - Oslo: Universitetsforlaget. Opprinnelig foredrag i Prags lingvistiske krets 1943, utgitt i Studie z estetiky, Praha 1966

Noreng, Øystein (1974). Lesere og lesing: rapport om Den norske Bokklubbens lesersosiologiske undersøkelse. Oslo : Den norske Bokklubben

Pearce, Lynne (1994). Reading dialogics. - London: Edward Arnold

Sjklovskij, Viktor (1917/1971). Konsten som grepp. - I: Form och struktur / valda av Kurt Aspelin och Bengt A. Lundberg. - Stockholm: Bokförlaget Pan/Norstedts. - Opprinnelig utgitt i 1917

Shepherd, David. Bakhtin and the Reader. - I: Hirschop, Ken (1991). Bakhtin and Cultural Theory / Hirschop, Ken and David Shepherd (ed.). - Manchester and New York : Manchester University Press.

Slaattelid, Rasmus T. (1998). Bakhtins translingvistikk. I: Bakhtin, M.M. (1979/1998). Spørsmålet om talegenrane. Bergen: Ariadne forlag

Skei, Hans H. (1993). Resepsjonestetikk og reader-response-kritikk. - I Kittang, A. et. al. Moderne litteraturteori: en innføring. - Oslo: Universitetsforlaget

Smidt, Jofrid Karner (1999). En kritisk lesning av Wolfgang Isers resepsjonsestetikk. - I: Tekstblikk: rapport fra forskersymposium i nordisk nettverk for tekst- og litteraturpedagogikk / redigert av Elise Seip Tønnessen og Eva Maagerø. - København: TemaNord

Smidt, Jofrid Karner (2002). Mellom elite og publikum: littercer smak og litteraturformidling blant bibliotekarer I norske folkebibliotek. - Oslo: Unipub

Smidt, Jofrid Karner (2010). "Dette er noe jeg har hatt bare for meg sjøl”: om menn, lesing og litteraturinteresse. Manuskript, foreløpig upublisert 
Steiner, Peter (1977). Jan Mukařovský's structural aesthetics. I: Structure, sign and function: selected essays by Jan Mukařovský. - New Haven: Yale University Press

Sætre, Lars (1989). Intensjonalitet som problem i Jan Mukařovskýs litterære estetikk. - I: Edda. - h. 4 (1989)

Tønnesson, Johan L. (2004). Tekst som partitur. Oslo: Unipub

Tønnesson, Johan (2008). Hva er sakprosa. - Oslo:Universitetsforlaget

Vold, Jan Erik (1967). Kunst og Vietnam. I: Dikt og sak. - Oslo: Det Norske Studentersamfund/Universitetsforlaget. - Opprinnelig trykt i Dagbladet 12.08.1965

Volosjinov, V.N. (1996). Marxism and the philosophy of language. - $6^{\text {th }}$ print. - Cambridge, Mass. : Harvard University Press. - Cop. 1986. - Originalens tittel: Marksizm i filosofiia iazyka, 1929 